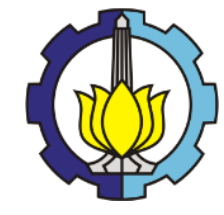

$8^{\text {th }}$ International Conference on

Architecture Research and Design (AR+DC)

1-2 November 2016

\title{
Transformation of gated community in the last three decades in Medan City, Indonesia
}

\author{
Dwira Nirfalini Aulia ${ }^{\mathrm{a}^{*}}$, Beny OY Marpaung ${ }^{\mathrm{a}}$ \\ ${ }^{a}$ Department of Architecture University of Sumatera Utara, Jl. Perpustakaan Gedung J07, Medan 20155, Indonesia \\ *Corresponding author. Tel.: +6261-8219525; +6281361717360. \\ E-mail address:dwira_aulia@yahoo.com; dwira.nirfalini@usu.ac.id
}

\begin{abstract}
The growth and development of Gated Community are happening around the world with no exception in Indonesia. The development happened because of rapid urban growth caused by urbanization. The important results from studying the transformation of gated community are the trend and factors that cause the change. The purpose of this research is to predict, prepare and control the growth of formal urban housing in the future. Factors led to the emergence and growing rapidly of a gated community in Southeast Asia is a combination of socio-economic background, culture, and security. Research is conducted by two approaches. Firstly, are the external aspects such as regulation of formal housing, political condition, and real estate market condition. Secondly, are the internal issues such as the concept of settlement planning and the characteristics of the occupants. This study was conducted in three residential development in the city of Medan which represent in the 1980's, 1990's and 2000's, namely Taman Setia Budi Indah, Graha Bumi Asri and Graha Metropolitan. The research's result shows the factors of changes occur in the privatization of public space, exclusivity and the need for security. The indirect phenomenon of gated community growth is a reflection of a modern city life's critique, because of the safety reduced. If these are not anticipated soon, it will form the structure of fragmented urban space with the privatization of public space legally.
\end{abstract}

Keywords: gated community; transformation

\section{Introduction}

Gated Community is a community who controlled the dwelling area to protect themselves from the crime and things that are not desirable (Atkinson \& Blandy, 2005). This area has a fence and gate to be able to control or restrict access to residential areas. The existence of a gated community in Indonesia initially established because of ethnicities such as Kampong Bali, Kampong Arab, Kampong China and others. Gardu as a marker of community in this era (Kusno, 2006). Although the physical appearance of the fence does not look like a gated community now, the concept of the society which is living in clusters remains the same. Then in the early of 1970's, marked by the government's efforts to encourage the involvement of private sector to developed housing supply made the emergence of a second type form of gated community. But the development of planned settlement by the developer cannot be separated by settlements that have been there before. Often the new planned settlement becomes into particular cluster between random settlements that have been there before. In addition to causing social conflict between these two types of arrangements, spatial patterns formed in Indonesia's city is a mixture that shows alternating between organized settlement patterns and not (Dieleman, 2011).

Gated community has an influence not only on the pattern of daily activities but also on the shape and function of the city (Landman, 2000). The long term snowball effect will have a negative impact on the sustainability of urban spatial arrangement, as well as the efficient and function of urban environment. Besides, privatization of 
urban area also has a potential conflict between the private developer and the local government in managing the housing area.

The more worrying phenomenon is the development of small scale gated settlement which organized by the community independently. Small-scale forms of gated settlement have arisen in the urban area based on the housing demand. The lack of sufficient theoretical platform from the scientists led to the absence of regulations from the government to anticipate this form of settlement. This condition is feared to open new problems such as the rapid change of land use and uncontrolled disintegration from the wealthy and poor society and the rise of a new hierarchy of society (Widhyharto, 2009).

The benefits of this research are: (1) Knowing the transformation of the formal housing can predict the pattern of growth and development of the city horizontally (2) The government can anticipate the growth and development of urban infrastructure network (3) The changes of planning practice in the Reformation's era, which occurred transformation of the paradigm of centralized capitalist toward the model of decentralized democratic and led to the ideas of good governance (Winarso, 2005). Knowing the change that occurs can help control the growth and development of the city.

\section{Research Theory and Method}

\subsection{Gated Community}

Theoretically, there are three arguments to a gated community mentioned by (Le Goix, 2005). First, gated community is a form of physical and tangible expressions of social change after the industrial revolution (fragmentation, individualistic and the increase of population). Urban conditions in Indonesia as a developing country made the city most fragmented and individualistic. Refers to the development of cities in developed countries, we adopted the forms of urban development indirectly. The forms of gated community will reinforce the fragmentation and individualistic. Second, gated community is a symptom of the urban disease, including the social classification. Social categorization and segregation are growing rapidly in Indonesia's city. This pattern also had been implanted by the Dutch colonial when Indonesia was colonized. Third, the development of fragmentation and individualism emerges private elite group opposed to the welfare distribution system which creates the assumption of inefficient public services. The third argument above is the background why gated community thrives in Indonesia. Gated community located in Southeast Asia can be seen as a mixture of social purposes, security and investment (Leisch, 2002).

The third argument above shows that from the perspective of consumers, the form of a gated housing will give a sense of identity of a community which has a strong appeal, especially to established society. While the perspective of the government, the form of a gated housing provides better tax revenue and the responsibility of governments to provide public facilities already provided by the private developer.

The types of gated community in the United States as follows: (1) Community lifestyle, which was created by the developer to increase the consumerism of society to leisure and comfort. Later this community will grow and form a new city. (2) Community prestige, which is created based on economic class and status. In this community, prestige and image become necessary, followed by privacy and security. (3) Community safety zones, building fences and gates for the safety mechanisms (Blakely \& Snyder, 1995). This community is changing housing environment by closing all access and employ security guards unit. The three types of gated community are also seen growth and development in cities in developing countries such as in Southeast Asia.

\subsection{The development of the Southeast Asia cities}

The rapid growth and development of urban settlements are seen in nearly all cities in the world, especially in cities in developing countries. This phenomenon is referred to as a paradigm of formal-informal sectors. In the 1980 's the focus has shifted to the 'city-world' which is a product of international trade, financial internationalization and global network strategy of multinational corporations. Then in the early 1990's the impact of global pressure changing the local culture identity in the Southeast Asia's cities were widely studied by experts (Dick \& Rimmer, 1998). The rise of income and the growing of middle-class urban society have created urban dynamics in Southeast 
Asia. The growth has attracted investment and the growth of satellite towns around the city center which is especially noticeable in the city of Jakarta, Manila and Singapore. The growth is in line with the development of settlements in the form of a gated community.

\subsection{The development of gated community}

Some researchers have undertaken research on the growth and development of the city and classify time per decade of growth. A decade of growth is considered capable of describing a form of settlement's transformation. The method of secondary data collection on the development of gated community in the world is based on the journals of the gated community, published a decade in front the time. In the era of 1980's, the culture and urban morphology have changed with the growth of mix-use complex, including offices, shopping, and recreation in urban areas. The change of urban space consumption is associated with the investment cycle and also reflects the changes of the institution. The first step in 1980's is marked with the growth of gated community in the suburban area. At this time, the classification of gated community looks as described by (Blakely \& Snyder, 1995) which are elite community for the wealthy and famous society, recreation and lifestyle community and the security community. The gated community also began to appear in Medan city. Taman Setia Budi Indah Housing estate is one of the pioneers of gated community. The property is located in the southern district of the city where at the same time the area is still undeveloped as it is today.

In the era of 1990s, the gated community is growing rapidly, especially in the suburban area. Research on gated community transformation from social and economic carried out by $(\mathrm{Wu}, 2005)$ in the Chinese socialist state. He highlights the classification of gated community mentioned by (Blakely \& Snyder, 1995) will be different on the levels of the implementation. Lifestyle community is formed because of common interests. Community prestige is formed as a product of social segregation. Community safety zone was created in response to a reduction in safety. The function of the fence is also different in each community. At the community lifestyle, the wall serves to clarify the services inside and outside the wall. In community prestige, the fence acts as a symbol to mark a quality environment. This type of communities usually offers shelter only. As such, clarifying the boundaries of service areas is not an important issue. For the safe zone community, the fence serves only for practical functions to improve security. In the era of 1990s has developed housing estates in Medan city, accordance with the growth of real estate market in Indonesia.

In the era of 2000s, there has been a transformation in the urban settlements. (Pradoto, 2011) conducted a study on the changes in urban settlements to understand the process of urbanization. The rapid growth of the city limits was triggered by the need for housing. Urban agglomeration occurs in big cities in Java's island. (Tsai Yen-Ling, 2011) describes the gated community in Indonesia form an exclusive housing cluster for Chinese ethnicity in Indonesia. The growth of Chinese ethnicities residents choose to live in a gated community because from history evidence and the gate fence is always used to restrict Chinese ethnicities and native. In this era, housing cluster based on ethnicity and social segregation is become increasingly apparent, and each developer competes to establish the exclusivity to attract housing buyer. In the 2000s, has developed dozens of gated housing in Medan city. Figure 1 below shows the distribution of gated housing. 


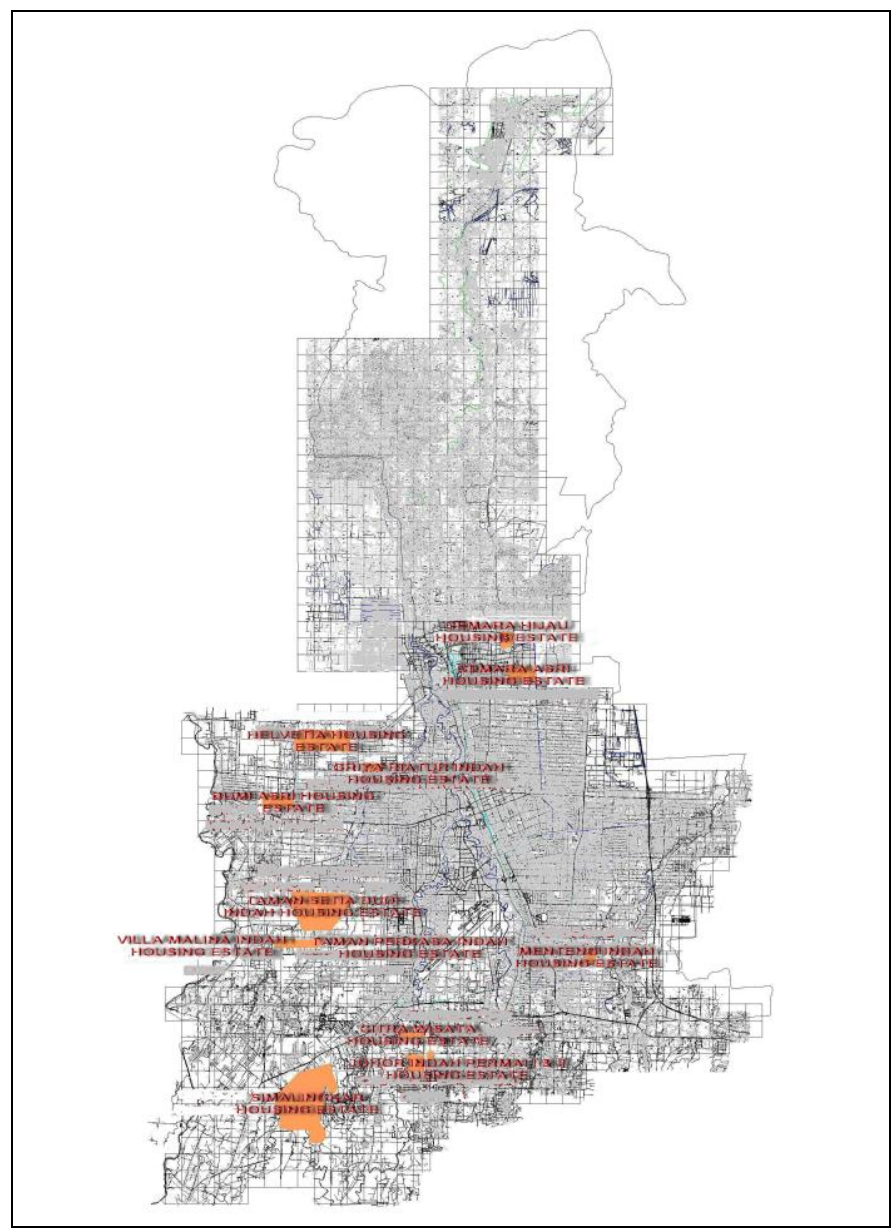

Fig. 1. The distribution of gated housing in Medan city in the 2000s

\section{Transformation gated community in Medan City, Indonesia}

\subsection{Research Method}

The research approach is positivistic (quantitative approach) which is more concerned with the focus of investigation variable. Then the variables are described in each the process of the variable. The determination of 30years' time frame which is from the 1980s until 2000s because at this time frame, marks the rising of gated community in the city of Medan. The study of the physical condition of gated community is Taman Setia Budi Indah Estate as a case study of mass formal housing in the era of 1980s. Then it was followed by Bumi Asri Estate in the era of 1990s and Graha Helvetia Metropolitan Estate in the era of 2000s 


\section{Taman Setia Budi Indah Estate}

The location of Taman Setia Budi Indah in the district of Medan Selayang, Tanjung Rejo, Medan. This estate was built in 1985 on 220 ha land area. The development of housing is for the uppermiddle income consumer. The number of dwelling units is 2800. Developer: PT Ira Widya Utama

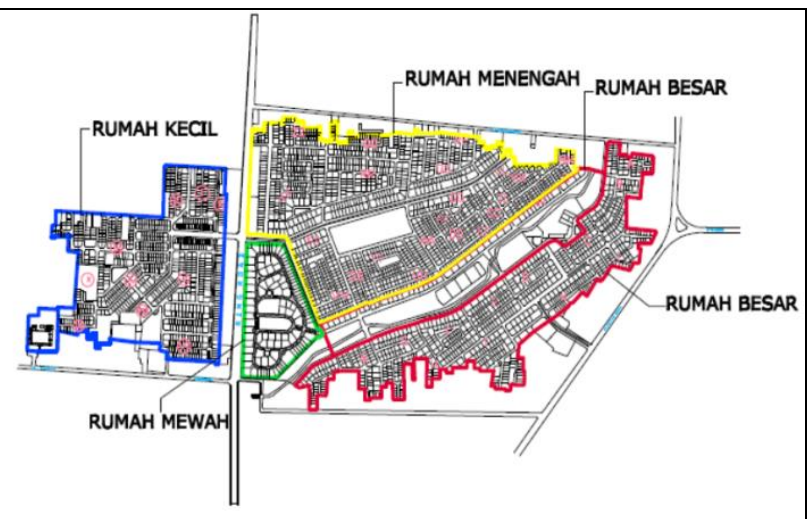

\section{Bumi Asri Estate}

PT Asri Pembangunan Catur Karya Cipta developing the estate in 1995 on 43 ha land area. Then the estate is growth and expanded into 70 ha of housing. The Estate has divided the territory into the blocks of the dwelling. The property has the security systems and utilities. Total occupancy: 1220 units

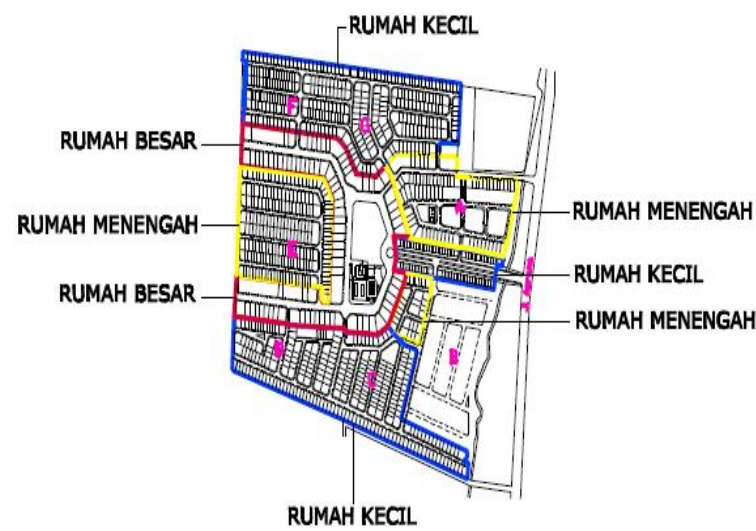

\section{Graha Metropolitan Estate}

PT. Agung Cemara Realty was developing the estate in 2002. The total area of settlement is 250 ha. The developer planning to build 1247 units of the dwelling but only 763 unit has already built and occupied now.

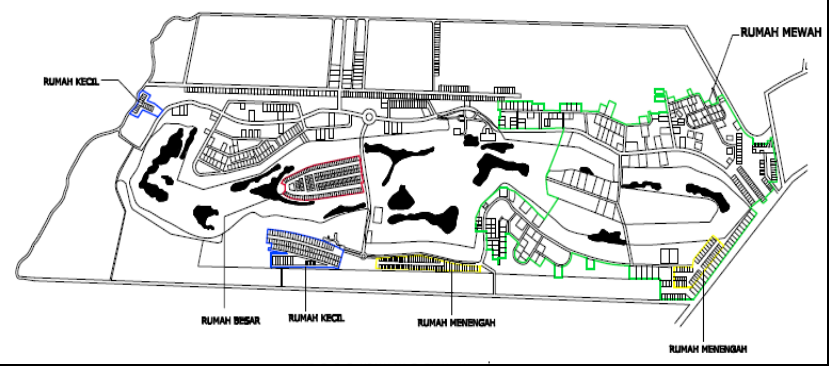

Fig. 2. Area Studies

The data of housing growth is unique because it can capture the combination of demographic trends (population growth, migration, family formation, trends settlements in urban, urbanization) and indicate the location and concentration of the human impact on the surrounding environment. The uniqueness allows estimating historical settlement patterns based on existing housing (Mockrin, Stewart, Radeloff, Hammer, \& Johnson, 2013).

The method of data analysis conducted with the external and internal influences on the gated community (Atkinson, Blandy, Flint, \& Lister, 2005). Methods for data analysis are spatial methods, frequency distribution methods, and comparative descriptive methods. Spatial methods can be used to analyze the spatial variables residential layouts (site plan of buildings, roads, and housing infrastructure) whereas frequency distribution method can be used to analyze the transformation of resident's types and characteristics over the last 30 years. The research framework can be seen in Figure 3 below 


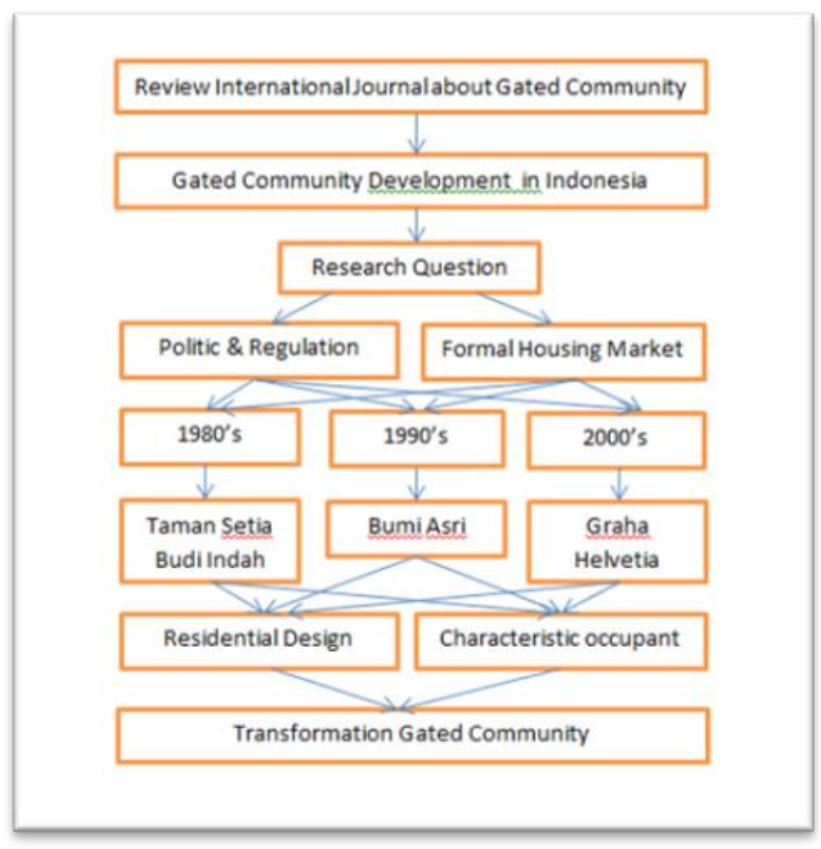

Fig. 3. Research Framework

\subsection{Result}

\subsubsection{Political and National Housing Policy}

The development of formal housing in Indonesia has been influenced by the changes of political condition and the National Housing Policy in the last three decades. The government developed public housing in 1976 by Perumnas (Perumahan Nasional) while private developer begins to build in 1974 by Real Estate Indonesia. However, the implementation of the KPR (Home Ownership Credit) for both housing providers was started in 1978. In the early 1980s, the private developer began developing housing construction.

In the mid of 1980s to 1997, business property is growing faster than the government housing development program. More than 20 large-scale of housing development managed by a private developer and $80 \%$ of these settlements are located in Jakarta City. Then, in 1998 the economic crisis happened in Indonesia, followed by the change of administration from the New Order regime into Reformation regime. The economic crisis and a change of government system in 1998-2002 led to the stagnancy of housing development (Tresani, 2000). The government issued a regulatory policy of large-scale housing development to the private institutions in the form of Government Regulation No. 80 /1999 about Kasiba Lisiba (Ready to Build Area). The implementation of this policy turned out to be tough because of limitation of land area and the cooperative arrangements between governments, and the private sector was not yet clear (HOMI Team Project \& Hoek-Smit, 2001). At the end of 20th century, the changes of social and political conditions, arrange decentralization in housing and settlement development.

\subsubsection{Formal housing market}

In the mid-1980s, private developers are not so active than the previous year. The first factor influencing the weaken of activity in private developer was the negative impact on the macroeconomic situation as a result of the fall in world oil prices and rupiah's value. The increasing of public spending substantially reduces the need for the property while property projects that already started before the economic crisis began to enter the market back. This 
condition causing the oversupply of housing. The second factor was the financial resources. Many developers were facing difficulties in finding sources of financing for the mega project property (Arai \& Kenichiro, 2001). In the early 1980s, many developers claimed that they are building a independent city. However, in reality, the majority of the occupants still commute to Jakarta for work (Sujarto 2003 in (Dieleman, 2011)).

These conditions changed drastically after Pakto October in 1988. The rise of fiscal condition affected the government's ability to provide investment needs. This situation changes the responsibility of the development large-scale urban housing from the government to the private sectors. Since the 1990s, private developers began to formulate a new city development model pioneered by Ciputra. All of these projects overlap with government regulations related to the management and development of the city. These conditions resulted in a business model where the development by private developers, cause the management and governance of primarily urban areas governed by commercial interests (Dieleman, 2011).

After the 2000s, an increasing number of people also raise the need for housing in urban areas. But the increase in demand for housing only occurs from potential demands instead of effective demands. Potential housing demand refers to people need housing for shelter with the inability to buy a house. The increase in potential demand for housing cannot be an indicator of improvement of local economy (Sulistiyani, 2002). Transformation of development housing in Indonesia can be seen in Figure 3 below.

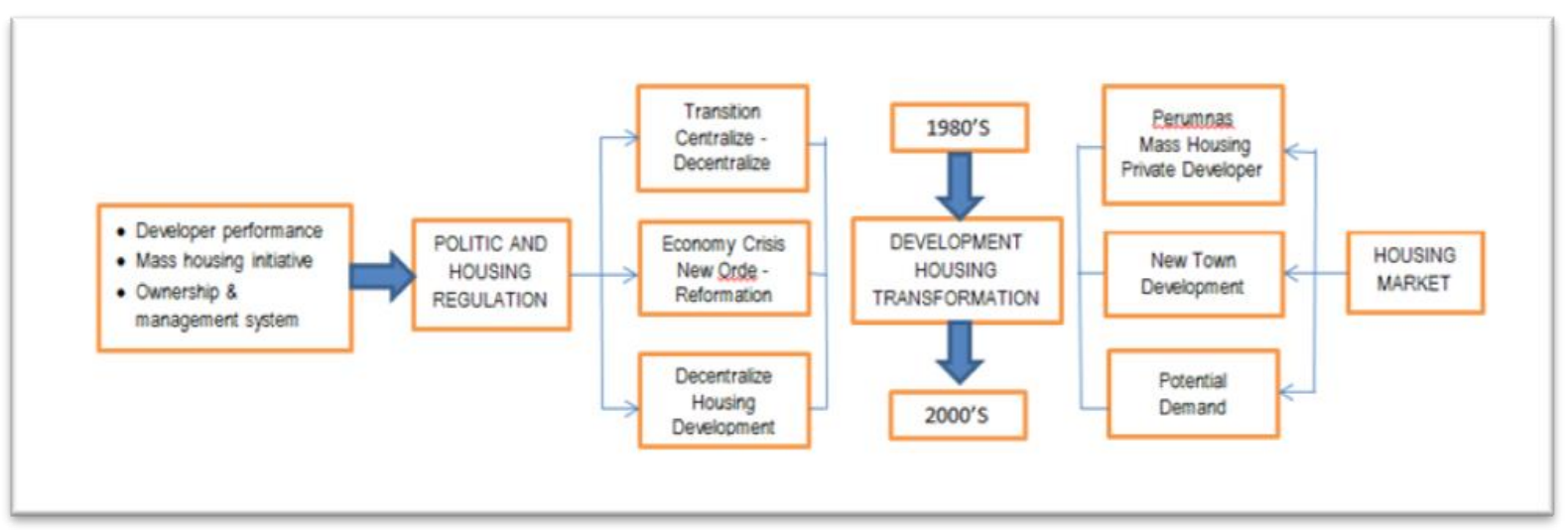

Fig. 4. Transformation of development housing in Indonesia

\subsubsection{Settlement design concept}

The change of housing policy and the real estate market in Indonesia is an external factor affecting the transformation of gated community. The observation of housing change shows how the three decades of the appearance of gated community in Medan city has last and sustain. The research which observes the effect of external factors on the planning of housing was also carried out by (Pouder \& Clark, 2009). The changes in the concept of settlement design included access, building pattern, circulation pattern, and housing facilities according to Untermann \& Small, 1983 in (Hidayati, 2013). In line with the trend of urbanization in developing countries, Indonesia has a rapid demographic growth in the urban area. The concentration of middle-income population is found in urban areas. They were able to buy a better environmental condition and willing to pay for clean air condition, parking space, greener neighborhood, security and clean water quality.

The important issue of gated community phenomenon is the privatization of public space (Seaton, Denton, Wolfteich, \& Kaufman, 1999). This issue has become an international phenomenon. Privatization of public space occurs when areas in a residential environment may only be used by residents of the housing. The outsider cannot utilized the environment without permission from the house manager. Regulations of using public spaces are managed by property managers. (Hamilton-Baillie, 2008) studied the regulation of public space, especially the use of the road network and public areas in a residential environment. The results showed there is a very close 
relationship between health issues and the design of the built environment. The housing estate borders the healthy environment in the residential area without considering the quality of the environment around the property. This condition shows the exclusivity with the surrounding environment.

The mobility of occupants determines the choice of housing location. The variables that affected the movement of the residents are age, marital status, economic status (South \& Crowder, 1997). When land prices are lower in the suburbs, a lot of housing estate growth in the 1980s era. This condition happened because the city center is becoming more crowded and jammed. More people prefer living in the suburbs so that full of pollutants in the city center can be avoided (Lucy \& Phillips, 2000). Inadequate condition of urban public transport system in Indonesia causes a new problem appears which is traffic jammed on the primary roads connecting the city center and suburbs area.

Table 1. Transformation factor analyze

\begin{tabular}{|c|c|}
\hline Transformation factor & Taman Setia Budi Indah Estate \\
\hline $\begin{array}{ll}\text { Public } & \text { Space } \\
\text { Privatization } & \end{array}$ & $\begin{array}{l}\text { The space formed by the placement } \\
\text { of housing units is used as public } \\
\text { space. There is passive urban public } \\
\text { space created. Open space is being } \\
\text { used as a private space by the } \\
\text { dwelling surroundings. The outsider } \\
\text { may utilize residential facility by } \\
\text { paying }\end{array}$ \\
\hline
\end{tabular}

Exclusivity

Security

Social segregation

Reasons choosing gated community along primary roads in the residential estate. The form of housing blocks is mixed from the medium house and luxury house.

Security is managed by the security forces formed by the resident's association. The officer monitors access entrance. In some specific areas is installed portal and placed a security guard posts there.

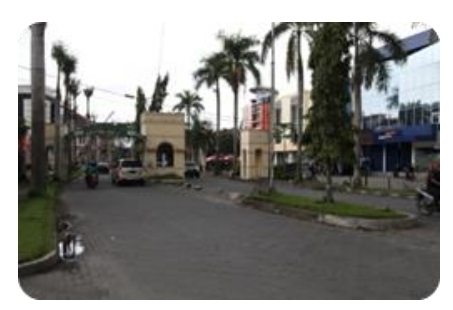

Social segregation is quite visible from the vast difference in luxury house lot and the more convenient access than small and medium unit.

Majority of the residents chose gated community for securities and facilities
The group of a luxury house located

\begin{tabular}{|c|c|}
\hline Bumi Asri Estate & Graha Metropolitan Estate \\
\hline $\begin{array}{l}\text { All occupants use the only one } \\
\text { public open space. The outsider may } \\
\text { utilize residential facility by paying }\end{array}$ & $\begin{array}{l}\text { There are many small cluster } \\
\text { housing in the residential estate. } \\
\text { Privatization of public space occurs } \\
\text { in the small and medium-sized } \\
\text { house such as the use of the road as } \\
\text { a car park. } \\
\text { The outsider may utilize residential } \\
\text { facility by paying }\end{array}$ \\
\hline
\end{tabular}

The location of luxury and medium house cluster is

near the center of the housing complex. Providing convenience for residents to achieve the center of the environment.

Security is managed by the security forces formed by the resident's association. The officer monitors access entrance.

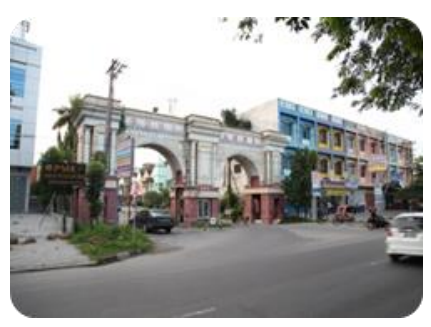

Exclusivity is clearly visible to form the clusters based on the type of dwelling unit

The developer managed housing security. Every cluster of housing has a post guard. Access entrance monitored by an officer.

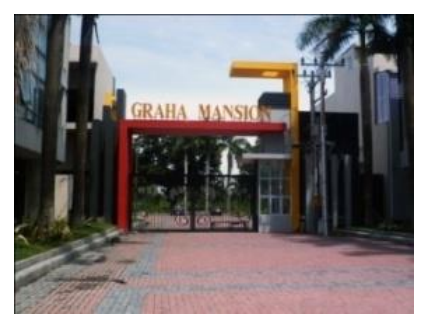

Social segregation visible from the placement of luxury and medium unit located near the center of housing complex, providing easier access to the unit, public spaces and larger dimension of road for the housing unit.

Majority of the residents chose gated community for securities, facilities and strategic housing complex location.
Social segregation visible by the cluster divided by housing types, prices and building specification

Majority of the residents chose gated community for securities, facilities and neighborhood characteristics 


\subsubsection{Types and characteristic of residents}

The changes in socio-economic conditions nationally or regionally correlate with the changes in the characteristics of gated community residents. Generally, residents in gated community are from middle income class or above because they are capable economically. (Peters \& Asian Studies Association of Australia, 2013) explained in the 1990s era, housing complex with middle income residents characteristics were widely develops. This resident class chose to settle in the cities as a result of inadequate city transportation and frequent traffic jams. As a result, there were many multistory mass housing developed in the center of the city to fulfill this demand.

Generally, human structure or function in the society is different from one another which mean that every social setting also has different structure or function. The characteristic of communities are transforming continuously. Community's transformation can be identified by indicators affecting the communities. The indicators are: environment, economy, social and politics. For example: everyday activities, natural disasters, economic changes and regulation implementation. Transformation of the communities may also occur as a result of the community member characteristic transformation (Kelly \& Steed, 2004). Examples of characteristic transformations are: sense of community, community pride, community competence, etc.

Gated community housing shows trends in housing ownership dominated by specific ethnicity group which is Chinese ethnicity. Housing environments affects social perception and integration, physically (housing location) and socially (residents activities) (Aulia \& Ismail, 2013). Research by (Manurung, 2005) on the Chinese ethnicity perception into the environment and the level of social integration on luxury environment housing suggested there are social gap objectively between Chinese ethnicity and native. Their sense of unity and attachment to ancestral land life pattern indicates a high ethnocentrism ethnic Chinese as well as the lack of care for the norms of social cultural life of others. This exclusivity has become increasingly apparent in the era of the 2000s.

\section{Conclusions}

The planning of formal housing changes in the last three decades. Factors transformed for the last three decades in gated community in Medan City are public space privatization, exclusivities, security needs and social segregation. Transformation in public space privatization is considerably even appeared in clusters of small-scale gated community. The smaller the scale, the more gated residential enclaves formed exclusivity. Even in a large scale housing estate, there were some clusters of exclusivity that are usually characterized by the build of gardu or gate. A group of residents makes the exclusive cluster based on the reason of security. Private developers acting as housing supplier for middle income or above are generally based on commercial business plan. This model blurred the lines of responsibilities between the government and private sectors. Social structure transformation in gated community correlates with Indonesia population's socio economic condition. Economic growth affects the community's social structure. This transformation are visible in populated cities in Indonesia generally and especially Medan City. Condition of Indonesian population during the period from 1970 to 2011 experienced a transition from the low-income economy into a middle income economy (Aviliani, Siregar, \& Hasanah, 2014).

\section{References}

Arai, \& Kenichiro. (2001). Only Yesterday in Jakarta : Property Boom and Consumptive Trends in the Late New Order Metropolitan City. The Southeast Asian Studies, 38(4), 481-511.

Atkinson, R., \& Blandy, S. (2005). Introduction: International Perspectives on The New Enclavism and the Rise of Gated Communities. Housing Studies, 20(2), 177-186. https://doi.org/10.1080/0267303042000331718

Atkinson, R., Blandy, S., Flint, J., \& Lister, D. (2005). Gated Cities of Today? Barricaded Residential Development in England. The Town Planning Review, 76(4), 401-422.

Aulia, D. N., \& Ismail, A. M. (2013). Residential Satisfaction of Middle Income Population: Medan city. Procedia - Social and Behavioral Sciences, 105, 674-683. https://doi.org/10.1016/j.sbspro.2013.11.070

Aviliani, A., Siregar, H., \& Hasanah, H. (2014). Addressing the Middle-Income Trap: Experience of Indonesia. Asian Social Science, 10(7), 163. https://doi.org/10.5539/ass.v10n7p163

Blakely, E. J., \& Snyder, M. G. (1995). Fortress America: Gated Communities in the United States - Edward J. Blakely, Mary Gail Snyder - 
Google Buku (2nd Edition). Washington: Brookings Institution Pres.

Dick, H. W., \& Rimmer, P. J. (1998). Beyond the Third World City: The New Urban Geography of South-east Asia. Urban Studies, 35(12), 2303-2321. https://doi.org/10.1080/0042098983890

Dieleman, M. (2011). New town development in Indonesia: Renegotiating, shaping and replacing institutions. Bijdragen Tot de Taal-, Land-En Volkenkunde, 167(1), 60-85. Retrieved from http://www.jstor.org/stable/41203121

Hamilton-Baillie, B. (2008). Towards shared space. URBAN DESIGN International, 13(2), 130-138. https://doi.org/10.1057/udi.2008.13

Hidayati, Z. (2013). HUBUNGAN LAYOUT PERUMAHAN DAN FAKTOR KRIMINALITAS DI PERUMNAS AIR PUTIH SAMARINDA. DIMENSI (Jurnal Teknik Arsitektur), 39(2), 83-90. https://doi.org/10.9744/dimensi.39.2.83-90

HOMI Team Project, \& Hoek-Smit, M. C. (2001). TECNICAL ASSISTANCE FOR POLICY DEVELOPMENT FOR ENABLING THE HOUSING MARKET TO WORK IN INDONESIA By. THE HOMI Project Team. Jakarta.

Kelly, G. J., \& Steed, L. G. (2004). Communities coping with change: A conceptual model. Journal of Community Psychology, 32(2), 201-216. https://doi.org/10.1002/jcop.10090

Kusno, A. (2006). Guardian of Memories: Gardu in Urban Java. Indonesia, (81), 95-149.

Landman, K. (2000). GATED COMMUNITIES AND URBAN SUSTAINABILITY: TAKING A CLOSER LOOK AT THE FUTURE. In Proceedings: Strategies for a Sustainable Built Environment (pp. 1-8). Pretoria.

Le Goix, R. (2005). Gated Communities: Sprawl and Social Segregation in Southern California. Housing Studies, 20 (2), $323-343$. https://doi.org/10.1080/026730303042000331808

Leisch, H. (2002). Gated communities in Indonesia. Cities, 19(5), 341-350. https://doi.org/10.1016/S0264-2751(02)00042-2

Lucy, W. H., \& Phillips, D. L. (2000). Suburban Decline: The Next Urban Crisis. Issues in Science and Technology, 17(1), 55-62.

Manurung, R. (2005). DAMPAK PERUMAHAN MEWAH TERHADAP PERSEPSI ETNIK CINA PADA DIRI DAN LINGKUNGANNYA (Studi Kasus pada Etnik Cina di Perumahan Setia Budi Indah, Kota Medan). Jurnal Wawasan, 11(2), 1-7.

Mockrin, M. H., Stewart, S. I., Radeloff, V. C., Hammer, R. B., \& Johnson, K. M. (2013). Spatial and temporal residential density patterns from 1940 to 2000 in and around the Northern Forest of the Northeastern United States. Population and Environment, 34(3), 400-419. https://doi.org/10.1007/s11111-012-0165-5

Peters, R., \& Asian Studies Association of Australia. (2013). Surabaya, 1945-2010 : neighbourhood, state and economy in Indonesia's city of struggle. NUS Press.

Pouder, R. W., \& Clark, J. D. (2009). Formulating strategic direction for a gated residential community. Property Management, 27(4), $216-227$. https://doi.org/10.1108/02637470910979989

Pradoto, W. (2011). Dynamics of Peri-urbanization and socioeconomic transformation: Case of Metropolitan Yogyakarta, Indonesia. International Journal of Arts \& Sciences, 4(27), 19-29.

Seaton, P., Denton, N. A., Wolfteich, C., \& Kaufman, E. (1999). Books in review : Fortress America: Gated Communities in the United States. Society, 37(1), 103-112. https://doi.org/10.1007/BF02686042

South, S. J., \& Crowder, K. D. (1997). Residential mobility between cities and suburbs: race, suburbanization, and back-to-the-city moves. Demography, 34(4), 525-538. https://doi.org/10.2307/3038307

Sulistiyani, A. T. (2002). Problema dan Kebijakan Perumahan di Perkotaan. JSP (Jurnal Ilmu Sosial Dan Ilmu Politik), 5(3), 327-344. https://doi.org/10.22146/JSP.11101

Tresani, N. (2000). The Viability of Public Housing in Indonesia. In Proceedings of 19th. EAROPH World Planning and Housing Congress and National Housing.

Tsai Yen-Ling. (2011). Spaces of Exclusion, Walls of Intimacy: Rethinking “Chinese Exclusivity” in Indonesia. Indonesia, (92), 125. https://doi.org/10.5728/indonesia.92.0125

Widhyharto, D. S. (2009). Komunitas Berpagar: Antara Inovasi Sosial dan Ketegangan Sosial (Studi Kasus Komunitas Berpagar di Propinsi D.I Yogyakarta, Indonesia). JSP (Jurnal Ilmu Sosial Dan Ilmu Politik), 13(2), 204-230. https://doi.org/10.22146/JSP.10962

Winarso, H. (2005). City for the rich. In The 8th International Conference of the Asian Planning Schools Association. Penang.

Wu, F. (2005). Rediscovering the "Gate" Under Market Transition: From Work-unit Compounds to Commodity Housing Enclaves. Housing Studies, 20(2), 235-254. https://doi.org/10.1080/026730303042000331754 